\title{
Revamping Finance via Fintech: Promises, Perils, and Practices in ASEAN
}

\section{KATIGBAK JOVITO JOSE}

\begin{abstract}
Fintech presents opportunities for ASEAN, especially in realising its objectives of financial integration, stability, and inclusion en route to a highly integrated and cohesive economy by 2025. Cognizant of the cited development's tremendous potential, ASEAN Member States have outlined specific goals, policy actions, and timelines in the 2025 ASEAN Economic Community Blueprint and in the AEC Consolidated Strategic Action Plan. Despite these strides, fintech-related efforts within ASEAN can be aptly characterised as mainly state-driven, hence the proliferation of varying standards and regulations, the fintech adoption divide, and the low level of trust of consumers in fintech platforms and service providers. Thus, AMS may consider the following policy options: (i) formulation and implementation of a region-wide fintech-specific framework; (ii) underpin infrastructure sharing among telecommunications companies, especially those operating in remote, rural areas; (iii) development of industry sandboxes for start-ups and SMEs; (iv) increase funding for cybersecurity-related projects; and (v) participate in APEC's CBPR initiative.
\end{abstract}

Keywords: fintech, financial inclusion, ASEAN Economic Community, regional integration, regulatory coherence

\section{Introduction}

The Association of Southeast Asian Nations (ASEAN) continues to be a key growth engine for the global economy as it contributed USD 2.8 trillion in total trade and secured almost USD 155 billion worth of foreign direct investment (FDI) in 2018. Fuelled by a population of almost 650 million, ASEAN boasts the world's fifth largest economy with a combined gross domestic product (GDP) of USD 3 trillion (ASEAN Secretariat, 2019b). In addition, the said grouping officially charted in 2015 its course toward an ASEAN Economic Community (AEC) to foster closer cooperation among the ten member states as well as projecting a unified ASEAN to external partners. Indeed, the AEC has well-intentioned objectives but persistent challenges complicate the substantial realisation of a well-functioning economic community.

Specifically, the lack of access to finance, especially by lower-income groups, hinders households and small and medium-sized enterprises (SMEs) in fulfilling basic needs, investing in productive endeavours, enhancing skills, and scaling up 
economic activities. ASEAN Member States (AMS) responded to this challenge by introducing novel, "targeted" financial offerings to certain groups but the emergence of financial technology (fintech) is viewed to thrust "open banking" into the mainstream as Internet-protocol-based financial transactions become more dominant. Since the 1950s, fintech has vastly evolved from merely supplementary instruments used by financial institutions to an entire industry characterised by mobile wallets, roboadvisors for wealth and retirement planning, payment apps, and crowdfunding and online lending platforms (Desai, 2015). Nevertheless, numerous impediments still exist such as access to government regulator data, outdated regulations, cybersecurity and data privacy, and lack of citizens' trust towards fintech.

Given the novelty of such phenomenon, this article primarily aims to review and examine the opportunities, challenges, and application of fintech in ASEAN. It is divided into five sections. The first part presents a brief history and definition of fintech, as well as the ecosystem of this booming development. The second section tackles the projected gains brought by fintech along with the accompanying costs and risks. The third segment delves into the nature and present state of fintech adoption in ASEAN by identifying best practices and notable initiatives. The penultimate segment outlines policy options and considerations for ASEAN as it adapts to the fast-changing landscape of fintech. The concluding section provides a synthesis of the previous discussions and enumerates key insights for ASEAN amidst its regional integration project.

\section{From Evolution to Revolution: A Review of Fintech's Rise}

Financial technology (fintech) can be characterised as the application of technologies to provide financial services. It was first coined in 1993 upon the creation of the Financial Services Technology Consortium by Citicorp (which later became Citigroup) (Hochstein, 2015). Further, Lee and Shin (2018) noted that this development began in the1990s as the internet revolution took off. In particular, the easier, instantaneous financial transactions among individuals and organisations, enabled by the internet and the World Wide Web (www), gave birth to the electronic finance (e-finance) phenomena. E-finance models encompass all types of financial services such as online banking, stock trading, and insurance. Consequently, the smartphone boom in the mid-2000s augmented these channels by ushering in innovative services such as mobile banking and payment (Lee and Shin, 2008).

Notwithstanding the novel nature of today's fintech, Arner et al. (2016) posit that the convergence of finance and technology initially occurred during the $19^{\text {th }}$ century. They enumerated three main periods of the fintech evolution. The first phase (18861967) witnessed the transition from analogue to digital. It featured the following: (i) installation of the transatlantic telegraph cable; (ii) charge plates and credit coins as substitutes for credit cards; (iii) creation of the Fedwire Funds Service to link all Federal Reserve Banks through telegraph; (iv) modern-day credit cards; (v) global telex network; and (vi) automated teller machines (ATMs) (Zimmerman, 2016). 
The second era (1967-2008) concentrated on the digitalisation of traditional financial services (Arner et al., 2016). Several financial institutions and mechanisms were introduced to facilitate cross-border transactions such as Clearing House Interbank Payment System, National Association of Securities Dealers Automated Quotations, and Society for Worldwide Interbank Financial Telecommunications. New e-finance schemes including online brokerage, banking, and shopping likewise emerged during this stage. In Europe, governments commenced the shift towards greater interconnection of their financial markets through key initiatives such as the Single European Act of 1986, financial liberalisation in the United Kingdom in 1986, and the Maastricht Treaty of 1992.

The latest period (2008-present) is essentially founded on the confluence of three factors, namely: (1) weakened trust of clients towards banks after the global financial crisis; (2) rise of smartphones; and (3) advanced application programming interfaces which allow the interoperability of different software and applications. Moreover, the distinguishing traits of today's fintech is the prominence of startups and technology firms in providing tailor-made services to a host of clients, as well as the velocity of change in many localities, especially in developing countries (Arner et al., 2016). As a result, individuals and organisations presently enjoy a multitude of digital financial services such as "mobile wallets, payment apps, robo-advisors for wealth and retirement planning, equity crowdfunding platforms for access to private and alternative investment opportunities, and online lending platforms" (Desai, 2015).

Notably, fintech's revolutionising force is projected to extensively affect the entire financial services sector (Heap and Pollari, 2015). At the institutional level, Schueffel (2016) underscored that "operations, comprising middle and backoffice client support, product servicing, and risk management functions will be affected and so will be distribution, encompassing online and physical channels, agents, financial advisers, and other third-parties" (p. 33). It must similarly adapt to emerging market segments, dynamic customer expectations, and evolving competitive structure and ecosystems (Deloitte, 2016). In its effort to establish a common taxonomy of the most impactful innovations, the World Economic Forum (WEF) (2015) identified six core functions of the extant financial services. These are: (i) payments; (ii) insurance; (iii) deposits and lending; (iv) capital-raising; (v) investment management; and (vi) market provisioning.

Lee and Shin (2018) mentioned five primary actors in the fintech ecosystem. First, fintech start-ups provide niche services to customers and pioneer the innovations in several areas. Secondly, traditional financial institutions contribute in such setting by reinventing their business models and strategies and by entering into partnerships with emerging fintech companies. Thirdly, technology developers create online platforms for both start-ups and incumbents to deliver improved services via social media, mobile devices, cloud computing, and algorithmic trading tools, among others. Fourthly, customers who are younger, wealthier, urban-based, and tech-savvy, serve as one of the main revenue sources of fintech companies. Lastly, governments shape the ecosystem through regulations encompassing startups and traditional financial institutions. 


\section{Understanding the Promises and Perils of Fintech}

Innovations in the financial sector are traditionally perceived as a conduit of economic development since the $19^{\text {th }}$ century (Michalopoulos et al., 2011). They are also credited for a handful of finance-related improvements, such as better banking services (Merton, 1992; Berger, 2003), efficient capital allocation (Ross, 1976), complete markets (Grinblatt \& Longstaff, 2000), and more risk-sharing opportunities (Allen \& Gale, 1994). Beck et al. (2012) examined data from 32 high-income countries over the period 1996-2006, and found that a higher level of financial innovation is positively linked to a country's growth in capital and in gross domestic product (GDP) per capita.

Furthermore, fintech can substantially contribute in preserving financial stability through four main issue-areas, namely: (i) decentralisation and diversification; (ii) efficiency; (iii) transparency; and (iv) access to, and convenience of, financial services (Financial Stability Board, 2017). The first element pertains to the entry of new innovative players and models (e.g. big data processing in alternative lending, robo-advice in wealth management) which widens the range of services and options for customers. Accordingly, the emergence of fintech start-ups and service providers can lessen the adverse impact of financial shocks since the failure of a single institution does not result in a systemic shutdown.

The second dimension focuses on the efficiency gains brought by financial innovations. Specifically, the deployment of productivity-enhancing technologies by both incumbents and new entrants can lead to agile business models which ultimately benefit the economy as a whole. In the remittances sector, lower transactions costs and faster transaction execution due to fintech have resulted in declining fees for sending remittances and quicker flow of finance across borders.

The third facet refers to fintech's ability in promoting transparency through addressing information asymmetries and facilitating effective risk management and pricing. In particular, the use of technologies to collect, store, and analyse financial data at an unprecedented rate enables companies to instantly disseminate relevant information (e.g. fees and charges) to customers.

The last aspect may be regarded as the most important contribution of fintech from a development standpoint - financial inclusion. As previously discussed, the decentralisation and diversification of services have been instrumental in reducing the number of unbanked individuals and households, and in creating opportunities for the underserved and underbanked. Demirgüç-Kunt et al. (2018) posit that digitising payments of wages and government benefits can expand account ownership among the unbanked, as well as increase account utilisation among the banked. The adoption of fintech as an alternative to predominantly cash-based payments of utilities such as water and electricity may then stimulate the account utilisation rate among banked adults.

Conversely, the Financial Stability Board (FSB) (2017) identified two main categories of risks that fintech pose to the stability of the financial system. The first type refers to microfinancial risks which may emanate from either financial or operational sources. 
Financial sources encompass maturity mismatch, liquidity mismatch, and leverage. The first scenario is common in lending platforms and arises when loans are extended for a longer duration, or when an investor opts to prematurely sell their loan before maturity thereby generating rollover risk. The second predicament can be observed in fintech credit platforms due to their non-performance of liquidity transformation. The last risk is usually associated with business and consumer lending or equity crowdfunding platforms and happens when they borrow funds to finance temporary holdings of equity issuance or bonds (FSB, 2017).

Vulnerabilities may also arise from the operations of fintech firms. These include poor governance or process control, reliance on third-parties for certain services, balance sheet losses incurred by critical FMls, cybersecurity and data privacy issues, and legal/regulatory challenges. The last two risks can be characterised as mainstream issues given their reach, impact, and policy implications. An instructive case of a devastating cyber-attack is the 2016 online heist incident, which resulted in a whopping USD 81 million loss for the central bank of Bangladesh (Quadir, 2019). Customers are also wary of misuse of personal data and electronic fraud (Cortina \& Schmukler, 2018). Moreover, fintech-related regulations can be described as outdated, cumbersome, and even constraining to firms, especially start-ups, in many developing countries.

The second category pertains to macrofinancial risks, or system-wide vulnerabilities that may magnify shocks to the financial system therefore causing instability (FSB, 2017). Specific risks include contagion, procyclicality, excess volatility, and systematically-essential entities. The first predicament occurs when substantial losses incurred by a single fintech platform or sector spills over to other players or sectors. The second scenario is associated with availability of cheap debt and equity financing to start-ups and new entrants during an economic surge. The third risk stems from the use of algorithms and other technologies which amplifies the already volatile financial system. The last vulnerability relates to the displacement of traditional banks and the ascent of fintech firms as too-importantto-fail entities (FSB, 2017).

\section{Fintech in ASEAN: Current State of Play and Notable Initiatives}

Having the world's fifth largest economy and serving as home to around 650 million individuals in 2018, the Association of Southeast Asian Nations (ASEAN) has rightfully garnered the attention and interest of investors and fintech firms globally. To illustrate, ASEAN's fintech industry received USD 485 million worth of investments in 2018, which is over $140 \%$ bigger than the 2017 figure, according to CB Insights (2018). There are more than 600 fintech start-ups that operated in the region during the cited year. More importantly, the proliferation of fintech companies across ASEAN is viewed as a viable means in advancing financial inclusion, since over $50 \%$ of the adult population is unbanked and majority are poor and living in rural, far-flung areas (Demirgüç-Kunt et al., 2018). 
The 2019 benchmarking study undertaken by the Cambridge Centre for Alternative Finance (CCAF), Asian Development Bank Institute (ADBI), and FinTechSpace revealed key findings about the current fintech ecosystem in ASEAN. In terms of geographic breakdown, Singapore has the most number of fintech firms operating within the region (29\% share of the total), followed by Indonesia (17\%), Malaysia (11\%), Thailand (10\%), and the Philippines (7\%). The remaining portion is composed of firms from Cambodia, Vietnam, Myanmar, and other enterprises that operate within ASEAN but are based elsewhere. Digital lending is the primary business model of fintech firms (32\% share of the total), followed by digital payments $(26 \%)$, crowdfunding $(21 \%)$, enterprise technology for finance institutions (17\%), and artificial intelligence (AI), machine learning (ML), big data (15\%). Other types of business models include personal and enterprise financial management, trading capital markets, asset management, and Insure Technology (InsurTech).

The survey similarly showed that the primary customer of fintech start-ups and companies are individuals ( $42 \%$ of the total), but focus has been gradually shifting towards corporations (28\%) and small and medium-sized enterprises (22\%). Digital lending and digital payments platforms are the main transaction partners of individuals, while enterprise technology for financial institutions and $\mathrm{Al} / \mathrm{ML} /$ big data are for large corporations and SMEs. In addition, ASEAN fintech firms retain their market share and expand their customer base by prioritising strategies encompassing ease of customer use, speed of service, product/service cost, interoperability, and user interface.

Furthermore, fintech firms expressed a generally positive reception toward regulations, albeit the need to secure specific licences for their different products and/or services (CCAF, ADBI, FinTechSpace, 2019). Enterprises engaged in AI/ML/ big data, digital payments, and digital lending are the most satisfied due "adequate and appropriate" policies, while companies engaged in capital raising crowdfunding and enterprise technology for financial institutions are the least satisfied due to "excessive and too strict" regulations. Notably, fintech firms perceive cyber-attack and regulatory change as the top risks to their operations, followed by acquisition by incumbent or by competitor, increase in fraudulent activity across the ecosystem, shift in customer loyalty, and collapse due to malpractice.

As previously mentioned, regulatory agencies in ASEAN have developed and implemented frameworks and policies covering specific fintech sectors at the domestic level (CCAF, ADBI, FinTechSpace, 2019). For instance, Indonesia has introduced tailor-made regulations for peer-to-peer (P2P) lending, while Thailand is closely following suit. There are no bespoke regulations for P2P lending in Philippines, Vietnam, and Singapore, thus firms are governed by existing laws such as securities and anti-money laundering requirements. Furthermore, both Malaysia and Indonesia have already issued specific regulations for equity crowdfunding, which is contrary to the situation in Laos, Myanmar, and Vietnam. Regulatory agencies in Singapore and Thailand are viewed as leaders in digital payments promotion, but there are still region-wide differences in qualification requirements, kinds of operational licences, and types of service providers. Other measures 
implemented by financial authorities include favourable tax policies for fintech firms (e.g. Indonesia, Laos, Malaysia, Philippines) and co-working spaces among domestic firms (e.g. Malaysia, Philippines, Vietnam).

Regulatory agencies of AMS can then be credited for initiating a handful of regulatory innovations, namely: (i) establishment of innovation offices; (ii) regulatory technology (RegTech); and (iii) creation of regulatory sandboxes. First, several jurisdictions have formed innovation units to primarily cater to fintech development within their locality. They may perform a host of tasks such as overseeing innovation hubs and regulatory sandboxes, enforcing policy measures related to fintech innovation, and reviewing new offerings/services that fall outside of existing regulations (Alliance for Financial Inclusion, 2020). Innovation offices likewise act as liaison between regulatory agencies and fintech service providers.

Within the region and globally, the Monetary Authority of Singapore (MAS) is regarded as one of the first movers in fintech regulation. It established the FinTech and Innovation Group (FTIG) in 2015 which is tasked to develop regulatory policies and development strategies for technology and innovation, improve efficiency and risk-management, and advance competitiveness in the financial sector (MAS, n.d.). The FTIG is divided into three sub-offices namely, payments fintech, fintech infrastructure, and fintech ecosystem. Further, MAS institutionalised a Data Analytics Group (DAG) in 2017 to apply data analytics in strengthening the supervision of financial institutions and in enhancing organisational efficiency. DAG is composed of three sub-offices which are data governance and architecture, specialist analytics and visualisation, and supervisory technology. A Technology and Cyber Risk Supervision Department (TCRD) was also formed to develop technology risk management and cybersecurity strategy and policies for financial institutions and to undertake cybersurveillance over the latest cyber threats (MAS, n.d.).

Another possible model is the Bank of Thailand's (BOT) Financial Technology (FinTech) Department, which is comprised of both information technology (IT) and policy experts (Alliance for Financial Inclusion, 2020). The Department is primarily responsible for managing the BOT's regulatory sandbox and attains this by working in coordination with other departments such as payments system policy, bank supervision, and technology risk supervision. The Bank has also created multiple cross-functional "squad" teams to keep track of recent fintech-related developments. Across Southeast Asia, Brunei, Indonesia, and Malaysia have their respective innovation offices which may function as an education centre, a one-stop-shop, or a policy-making body (CCAF, ADBI, FinTechSpace, 2019).

Next, AMS have rolled out regulatory technology (RegTech) to effectively monitor fintech firms' compliance with standards and measures, and vice-versa. The adoption of RegTech is projected to produce more evidence-based, data-driven policy decisions by finance authorities and augment operational efficiency (Perlman, 2019). Fintech firms may likewise benefit from such innovation as large swaths of data can be collected, stored, and analysed instantly and be made available for regulatory compliance purposes. To illustrate, the Autoriti Monetari of Brunei Darussalam have deployed RegTech in building a centralised statistical system of financial data from external parties, while the Bank Negara Malaysia has furthered 
its open banking journey by promoting open application programming interface (API) covering motor insurance, credit cards, and SME financing. Singapore and Thailand have utilised RegTech for data governance and distributed ledger technology industry, respectively, while Philippines has begun exploring digital supervision technologies and techniques (CCAF, ADBI, FinTechSpace, 2019).

Lastly, financial authorities across ASEAN have implemented regulatory sandboxes to enable and encourage innovation within a well-defined environment. The $\mathrm{CCAF}, \mathrm{ADBI}$, and FinTechSpace define sandboxes as "formal regulatory programs that allow market participants to test new financial services or business models with live customers, subject to certain safeguards and oversight"(2019, p. 57). In the Philippines, the Bangko Sentral ng Pilipinas (BSP) is implementing a regulatory sandbox as part of its fintech roadmap. BSP Governor Benjamin Diokno highlighted five main steps under such a mechanism, otherwise known as test-and-learn approach:

“i) Allow for market to develop and innovations to take place;

ii) Proceed with flexibility yet with caution;

iii) Understand operating and business model;

iv) Adopt appropriate regulatory approach; and

v) Closely monitor developments and related issues" (2019).

Singapore remains a leader with over 40 applications and 140 types of guidance provided to firms and individuals. Brunei, Malaysia, and Vietnam have their own regulatory sandboxes, while both Thailand and Indonesia operate two sandboxes currently.

At the regional level, the ASEAN Financial Innovation Network (AFIN), ASEAN Bankers Association, and the International Finance Corporation, launched the API Exchange (APIX) in 2019 to catalyse synergies between financial institutions and fintech firms within the region. The APIX is the world's first cross-jurisdictional, open architecture API which acts as both a marketplace and a sandbox (AFIN, 2020). Using this platform, fintech firms can help financial institutions in addressing business problems through innovative solutions, and users can purchase APIs for various objectives. Benefits of joining APIX include greater visibility with investors, better market credibility, less costly prototype and proof of concepts (POF) development, and intellectual property protection. Over 50 financial institutions and more than 330 fintech firms have already tapped APIX to upgrade their innovation capabilities and to scale their unique products.

\section{Advancing Fintech within AEC: Options and Considerations}

Notwithstanding the aforementioned strides, AMS still face several challenges in improving fintech uptake across the region. Based on the ASEAN Economic Community (AEC) Blueprint 2025, fintech-related goals, efforts, and initiatives can 
be found under section A.4. Financial Integration, Financial Inclusion, and Financial Stability of pillar A. A Highly Integrated and Cohesive Economy (ASEAN Secretariat, 2016). Thus, the succeeding paragraphs review the salient features of relevant ASEAN documents, along with the key issues confronting AMS and the regional bloc. Policy options and considerations at the regional level are similarly explored.

As stipulated in the AEC 2025 Consolidated Strategic Action Plan (CSAP), financial integration will be pursued through "increasing the role of ASEAN indigenous banks, having more integrated insurance markets, and having more connected capital markets" (ASEAN Secretariat, 2018). Key ASEAN frameworks related to this endeavour are the Banking Integration Framework (ABIF), Framework Agreement on Services (AFAS)/Trade in Services Agreement (ATISA), and Collective Investment Scheme (CIS) Framework. Different working committees at the regional level monitor the progress and milestones of the AMS toward financial integration.

In the field of payment and settlement systems, AMS have begun adopting ISO 20022, which lays out the international standard for data interchange among financial institutions. Brunei, Cambodia, Philippines, and Thailand have enacted measures in congruence with ISO 20022 for Real-Time Retail Payments, while only Brunei adopted ISO 20022 for Large Value Payment Systems as of 2018 (World Bank \& ASEAN WC-FINC, 2019). More recently, an ASEAN Payments Policy Framework (APPF) was finalised which will link real-time retail payment infrastructures in AMS, hence making cross-border transactions somehow comparable to domestic payments. These initiatives are expected to support a freer flow of retail payments within Southeast Asia. There are also efforts focusing on remittances through formal channels and stronger consumer protection (ASEAN Secretariat, 2019a).

Financial stability is another issue-area covered by AEC 2025 CSAP. The ABIF seeks to attain this by raising the level of regulatory transparency, standards, and coherence, and by espousing cooperation on supervisory and crisis recovery, management, and resolution arrangements. In addition, the AEC 2025 SAP for Financial Integration 2016-2025 provides that financial market infrastructures (FMIs) within the region must comply with international standards such as the Principles for FMIs. It also cites the need to craft an appropriate regulatory framework for innovations to effectively address novel risks and vulnerabilities. Some of the ABIF's financial integration-related milestones include a regulatory scan of AMS, Guidelines for Monitoring and Reporting on the Progress of Agreements under ABIF, including monitoring templates, key performance indicators for banking, and oversight of intra-ASEAN indigenous banks and intra-ASEAN financing.

In spite of the comprehensive nature of both the abovementioned documents, the lack of harmonisation among regulatory initiatives continues to challenge ASEAN's march toward regional integration. This is evidenced by varying data protection standards in different jurisdictions, fragmented platforms and policies, specifically on cross-border payments, and a multitude of regulatory approaches on cryptocurrencies. The absence of formal industry organisations in many fintech sectors have also hampered the development of self-regulation/policing mechanisms, which may lessen the burden on regulatory agencies (CCAF, ADBI, 
FinTechSpace, 2019). Moreover, overregulation of certain sectors such as equity crowdfunding and enterprise technology for financial institutions is a real concern since burdensome requirements and licences hinder firms from actually operating in a particular jurisdiction. The presence of different authorities such as financial, competition, telecommunication, and/or anti-money laundering simultaneously regulating a single digital financial services (DFS) provider or product have resulted in overlapping regulations and silos (World Bank \& ASEAN WC-FINC, 2019).

Thus, AMS may consider the formulation and implementation of a region-wide fintech-specific framework to effectively steer the Association toward financial integration. Existing frameworks such as the APPF, AFAS/ATISA, and ABIF may serve as vital building blocks or guideposts in the development of an ASEAN Framework on Fintech/Digital Financial Services to ensure its alignment with the 2025 AEC CSAP and AEC SAP for Financial Integration 2016-2025. Working committees at the regional level will therefore play a critical role in determining the depth and pace of such undertaking. Subsequently, AMS may identify "champions" to effectively streamline the proposed Framework and to enhance its visibility and agenda importance at both the domestic and regional levels. Singapore and Malaysia seem to fit the description, and Thailand, Philippines, and Indonesia are quickly catching-up.

In terms of content, ASEAN Member States may include a commonly-agreed definition of fintech to establish a clear outline of the scope and parties covered in the Framework. They may likewise incorporate a provision on the establishment of a Working Committee on Fintech composed of regulatory authorities of AMS, which will be responsible for the development of fintech-related policies and activities, as well as the oversight of States' progress in increasing fintech uptake among members of the ecosystem. The pooling of resources and manpower under a single regional body may lead to a deeper level of fintech adoption. Moreover, the Framework may encourage the greater participation (and even the creation) of formal industry organisations of different fintech sectors in region-wide initiatives to foster synergies between AMS and private sector partners.

Furthermore, Member States may look into the development of self-regulation mechanisms to reduce the burden on regulatory agencies' capacity. It is crucial to emphasise that self-policing should not be perceived as an enabler of regulatory arbitrage or regulatory capture, but instead as a means to enhance compliance of firms due to peer-to-peer monitoring. This decentralised type of oversight is appropriate for fintech products/services due to their wide-ranging nature and peculiar dynamics.

Along with financial integration and financial stability, financial inclusion is the last component of section A.4. of the AEC Blueprint 2025. The Working Committee on Financial Inclusion (WC-FINC) is tasked to facilitate the attainment of such goal, and is guided by the ASEAN Financial Inclusion Framework. The Framework has four main objectives: "(i) support national financial inclusion strategy and implementation plan; (ii) elevate capacity building of AMS to enhance financial inclusion ecosystem; (iii) promote innovative financial inclusion via digital platforms; and (iv) increase awareness on financial inclusion and consumer protection" 
(Bangko Sentral ng Pilipinas, 2015). The survey done by WC-FINC found that six AMS have Roadmaps or National Strategies for Financial Inclusion respectively, and three of them have Roadmaps or National Strategies for Financial Education. All ten AMS have instituted public credit registry or credit bureau, while seven Member States operate their respective credit guarantee institution (World Bank \& ASEAN WC-FINC, 2019).

Key documents that enable the operationalisation of the ASEAN Financial Inclusion Framework include the Guidance Notes on National Financial Inclusion Strategies, Guidance Notes on Financial Education and Consumer Protection, Guidance Notes on Digital Financial Services (DFS), and Survey Report on Digital Financial Services in AMS (ASEAN Secretariat, 2019a). Member States are also in the process of creating Guidance Notes on Monitoring Financial Inclusion Toolkit. The ASEAN Insurance Regulators' Meeting (AIRM) is similarly working on a Framework for Microinsurance Product to expand the coverage of commercial and social insurance schemes within the region.

Consequently, these undertakings have led to a lower financial exclusion rate at around $37 \%$ in 2018, from $44 \%$ in 2016 , according to the ASEAN Integration Report 2019. Readiness of financial inclusion infrastructure among Member States have likewise improved to $74 \%$ in 2018 , from $70 \%$ in 2016 . The surge in digital payments systems utilisation, diffusion of digital technology, and digital financial services innovations are cited as main drivers of financial inclusion in ASEAN.

Despite these accomplishments, the regional bloc's financial inclusion project is still plagued by two perennial issues, namely, digital divide, and low level of trust and confidence in fintech platforms and service providers. The first challenge can be observed in the disparity in number of fintech firms operating in the region. Particularly, Singaporean, Indonesian, Malaysian, Thai, and Philippines enterprises make up more than $70 \%$ of the total, while CLMV countries and other non-ASEAN firms comprise the remaining 26\% (CCAF, ADBI, and FinTechSpace, 2019).

Further, ASEAN-5 countries (Singapore, Malaysia, Thailand, Indonesia, Philippines) have an average of almost $70 \%$ of the adult population with a bank account, which is far greater than the CLMV (Cambodia, Laos, Myanmar, Vietnam) average of $27 \%$ (Demirgüç-Kunt et al., 2018). The lack of fintech-related infrastructure, especially in rural, remote areas, in several localities within Southeast Asia is seen as another perpetuator of the lingering divide. With the exception of Singapore, fixed broadband speed in the region is also lagging, with Philippines, Brunei, Indonesia, Cambodia, and Myanmar falling outside the top 100 (The ASEAN Post, 2019a). Evidently, these factors substantially contribute to the impeded growth of fintech ecosystems across several jurisdictions in the region. Hence, ASEAN and its Member States may assess a couple of policy recommendations in addressing the digital divide.

A logical pathway is the promotion of infrastructure sharing among telecommunications companies to reach underserved and disconnected areas (Garcia \& Kelly, 2016). It may be in the form of either mutualisation (i.e. a common facility operated by all market players) or a cooperative model (i.e. infrastructure is built with other linear infrastructures). The sharing of facilities (e.g. site, cell tower, 
base station, network) is expected to raise the quality of internet service and speed as more resources can be allotted for research and development of companies. Ultimately, a competitive telecom industry benefits the society, as more citizens can enjoy a whole spectrum of services and products at fair market prices. However, implementing an effective infrastructure sharing mechanism entails the cooperation of various market participants with competing interests. ASEAN governments are hence given the unenviable task of bringing together all the concerned parties and guiding them towards the right direction. They must similarly assess and account for the economic and regulatory implications of adopting such setting.

To support fintech start-ups and even SMEs, AMS, with the help of AFIN, may mainstream the development of industry sandboxes for fintech firms (World Bank \& ASEAN WC-FINC, 2019). This set up allows firms and industry players to collectively test proof concepts and new offerings in an environment without consumers. The industry sandboxes can simulate consumer behaviour to examine whether an application has met the functionality level aspired by the company. This policy option may fulfil two purposes: (1) nurture a culture of innovation through partnerships among ecosystem members; and (2) serve as a complementary to regulatory sandboxes. Member States may explore the possibility of providing fiscal incentives to fintech organisations and market participants that are actively engaged in industry sandboxes.

The last issue refers to the low level of confidence and trust of ASEAN citizens in fintech platforms and products/services. To illustrate, around $50-65 \%$ of digital buyers from the Philippines, Thailand, Indonesia, Vietnam, and Malaysia expressed their reluctance in sharing their financial information online (BBVA Research, 2017). The anxiety in disclosing personal data to companies, especially e-commerce firms, is fuelled by large-scale cyberattacks in Cambodia, Malaysia, Singapore, Thailand, and Philippines (ASEAN Today, 2018). The Asia Pacific Risk Centre estimates that data breaches globally cost around USD 2 trillion in 2019, and that hackers are $80 \%$ more likely to launch attacks against organisations in Asia (The ASEAN Post, 2019b). In the Global Cybersecurity Index 2018, Singapore remains to be a trailblazer in ASEAN (ranked $6^{\text {th }}$ globally), followed by Malaysia (ranked $8^{\text {th }}$ globally), Thailand (ranked $35^{\text {th }}$ globally), Indonesia (ranked $41^{\text {st }}$ globally), and Vietnam (58 globally). The Philippines, Laos, Myanmar, and Cambodia complete the list.

Notably, only Philippines, Singapore, and Thailand in the region have data protection laws and data privacy regulatory agencies. Thailand is set to join the group soon, while Indonesia is following suit. The adoption of the ASEAN Framework on Digital Data Governance to leaders in 2018 is a welcome development as the document aims to improve data management, advance harmonisation of data standards and regulations, and enhance intra-ASEAN data flows (Thomas, 2019). However, a lot of work still needs to be done. For instance, AMS may augment their expenditures on cybersecurity-related programs, as they spent only $0.06 \%$ of the region's GDP (USD 1.9 billion) in 2017. The allocation of more resources for a fortified cybersecurity system may create additional savings for the government, which can then be utilised for provision of public services or reinvested in cybersecurity-related efforts. Furthermore, Member States, except Singapore and Philippines, may 
participate in the Asia-Pacific Economic Cooperation (APEC) Forum's Cross-Border Privacy Rules (CBPR) which is "a government-backed data privacy certification (scheme) that companies can (voluntarily) join to demonstrate compliance with internationally-recognized data privacy protections" (APEC, 2019) Evidently, AMS' involvement in the CBPR can be taken as a demonstration of their commitment to consumer protection and data privacy.

\section{The Future of Fintech in ASEAN}

Indeed, fintech presents opportunities for Southeast Asia, specifically in upholding financial stability and in advancing financial integration. More importantly, financial innovations have the potential to level the playing field for all players and empower the unreached and underserved portions of the population. Recognising the tremendous promise of such development, ASEAN has laid the groundwork by setting specific goals, which can be found in the 2025 AEC Blueprint and AEC CSAP, and by developing region-wide frameworks such as the APPF, AFAS/ ATISA, and ABIF. Nevertheless, fintech-related efforts within ASEAN can be aptly characterised as mainly state-driven, hence the proliferation of varying standards and regulations, fintech adoption divide, and low level of trust of consumers in fintech platforms and service providers.

Accordingly, AMS may consider the following policy options: (i) formulation and implementation of a region-wide fintech-specific framework; (ii) underpin infrastructure sharing among telecommunications companies, especially those operating in remote, rural areas; (iii) development of industry sandboxes for startups and SMEs; (iv) increase funding for cybersecurity-related projects; and (v) participate in APEC's CBPR initiative. The role of proactive, innovation-friendly policies and regulatory agencies at the domestic level are paramount in realising these recommendations.

In the medium-run, fintech adoption among Member States appears to be on an upward trend amid the Fourth Industrial Revolution. This phenomenon has prompted governments, private sector, and consumers alike to adapt to unprecedented technologies and living standards and to creatively manage new risks and vulnerabilities. The current Covid-19 pandemic has also been a catalyst of greater fintech uptake, as firms and consumers are pushed towards digital platforms and tools in carrying out their operations and even mundane activities. Nevertheless, AMS should exercise due diligence and caution by establishing fintech-related safeguards and mechanisms against underlying risks and potential vulnerabilities.

In the long-run, it remains to be fully seen how the dynamics and politics of fintech will coexist with the ASEAN Way, which is characterised by incrementalism, consensus, and non-interference. The only obvious observation is that the complexity and cross-border nature of fintech processes and transactions entail deeper cooperation and agile synergies at the regional level, especially amid ASEAN's integration project. 


\section{Bibliography}

Alliance for Financial Inclusion. (2020). Creating Enabling Fintech Ecosystems: The Role of Regulators. Retrieved from https://www.afi-global.org/sites/default/ files/publications/2020-01/AFI_FinTech_SR_AW_digital_0.pdf.

Allen, F. \& Gale, D. (1994). Financial Innovation and Risk Sharing. Cambridge, MA: MIT Press.

APEC. (2019). What is the Cross-Border Privacy Rules System? Retrieved from https://www.apec.org/About-Us/About-APEC/Fact-Sheets/What-is-the-CrossBorder-Privacy-Rules-System.

Arner, D.W., Barberis, J., \& Buckley, R.P. (2016). 150 Years of Fintech: An Evolutionary Analysis. The Finsia Journal of Applied Finance 3, 22-29.

ASEAN Financial Innovation Network. (2020). About Us. Retrieved from https:// apixplatform.com/aboutapix.

ASEAN Secretariat. (2016). ASEAN Economic Community Blueprint 2025. Retrieved from https://www.asean.org/storage/2016/03/AECBP_2025r_ FINAL.pdf.

ASEAN Secretariat. (2018). ASEAN Economic Community 2025 Consolidated Strategic Action Plan. Retrieved from https://asean.org/wp-content/ uploads/2012/05/Updated-AEC-2025-CSAP-14-Aug-2018-final.pdf.

ASEAN Secretariat. (2019a). ASEAN Integration Report 2019. Retrieved from https://asean.org/storage/2019/11/ASEAN-integration-report-2019.pdf.

ASEAN Secretariat. (2019b). ASEAN Key Figures 2019. Retrieved from https://www.aseanstats.org/wp-content/uploads/2019/11/ASEAN_Key_ Figures_2019.pdf.

ASEAN Today. (2018). The ASEAN governments exploiting cybersecurity threats to expand authoritarian powers. ASEAN Today. Retrieved from https://www. aseantoday.com/2018/12/the-asean-governments-exploiting-cybersecuritythreats-to-expand-authoritarian-powers/.

Bangko Sentral ng Pilipinas. (2015). International Cooperation: Working Committee on Financial Inclusion (WC-FINC). Retrieved from http://www.bsp.gov.ph/ asean/wc_finc.asp.

BBVA Research. (2017). Fintech in Emerging ASEAN Trends and Prospects. Retrieved from https://www.bbvaresearch.com/en/publicaciones/fintech-inemerging-asean-trends-and-prospects/.

Beck, T., Tao, C., Chen, L., \& Song, F. (2012). Financial Innovation: The Bright and the Dark Sides. HKIMR Working Paper No. 5, 1-48.

Berger, A.N. (2003). The Economic Effects of Technological Progress: Evidence from the Banking Industry. Journal of Money, Credit and Banking, 35, 141-76.

CCAF, ADBI, FinTechSpace. (2019). ASEAN FinTech Ecosystem Benchmarking Study. Retrieved from https://jbs.cam.ac.uk/wp-content/uploads/2020/08/2019ccaf-asean-fintech-ecosystem-benchmarking-study.pdf. 
Cortina, J., \& Schmukler, S. (2018). The Fintech Revolution: A Threat to Global Banking? World Bank Research and Policy Briefs No. 125038, 1-4.

Deloitte. (2016). Disaggregating fintech: Brighter shades of disruption. Retrieved from https://www2.deloitte.com/content/dam/Deloitte/us/Documents/financialservices/us-fsi-disaggregating-fintech-brighter-shades-of-disruption.pdf.

Demirgüç-Kunt, A., Klapper, L., Singer, D., Ansar, S., \& Hess, J. (2018). The Global Findex Database 2017: Measuring Financial Inclusion and the Fintech Revolution. Washington, DC: World Bank.

Desai, F. (2015). The Evolution of Fintech. Forbes. Retrieved from https://www.forbes. $\mathrm{com} / \mathrm{sites} /$ falgunidesai/2015/12/13/the-evolution-of-fintech/\#51fd9a277175.

Diokno, B. (2019). Regulations and Policies to Empower Financial Institutions and Reach Undeserved Population through Technology and Innovation. Retrieved from http://www.bsp.gov.ph/printpage.asp?ref=http://www.bsp.gov. $\mathrm{ph} /$ publications/speeches. asp?id=678.

Garcia, J.M., \& Kelly, T. (2016). The Economics and Policy Implications of Infrastructure Sharing and Mutualisation in Africa. Retrieved from http:// pubdocs.worldbank.org/en/533261452529900341/WDR16-BP-InfrastructureMutualisation-Garcia.pdf.

Grinblatt, M. \& Longstaff, F.A. (2000). Financial Innovation and the Role of Derivative Securities: An Empirical Analysis of the Treasury STRIPS Program. Journal of Finance, 55, 1415-1436.

Financial Stability Board. (2017). Financial Stability Implications from Fintech: Supervisory and Regulatory Issues Raised by FinTech that Merit Authorities' Attention. Retrieved from https://www.fsb.org/wp-content/uploads/R270617.pdf.

Heap, T., \& Pollari, I. (2015). FINTECH 100 - Leading Global Fintech Innovators Report 2015. Retrieved from https://assets.kpmg/content/dam/kpmg/pdf/2015/12/ fintech-100-leading-innovators-2015.pdf.

Hochstein, M. (2015). Fintech (the Word, That Is) Evolves. American Banker. Retrieved from https://www.americanbanker.com/opinion/fintech-the-word-thatis-evolves.

KPMG. (2017). Value of Fintech. Retrieved from https://assets.kpmg/content/dam/ kpmg/uk/pdf/2017/10/value-of-fintech.pdf.

Lee, I., \& Shin, Y.J. (2018). Fintech: Ecosystem, business models, investment decisions, and challenges. Business Horizons 61, 35-46.

Merton, R.C. (1992). Financial Innovation and Economic Performance. Journal of Applied Corporate Finance, 4, 12-22.

Michalopoulos, S., Laeven, L., \& Levine, R. (2011). Financial Innovation and Endogenous Growth. Retrieved from https://www.sss.ias.edu/files/papers/ econpaper97.pdf.

Monetary Authority of Singapore. (n.d.). Fintech and Innovation Group. Retrieved from https://www.mas.gov.sg/who-we-are/Organisation-Structure/Fintech-andInnovation. 
Perlman, L. (2019). Fintech and Regtech: Data as the New Regulatory Honeypot. Retrieved from https://dfsobservatory.com/sites/default/files/Fintech\%20 and\%20Regtech\%20-\%20Perlman\%20Final.pdf.

Quadir, S. (2019). Bangladesh to sue Manila Bank over $\$ 81$ million cyber heist: cenbank governor. Reuters. Retrieved from https://www.reuters.com/article/ us-cyber-heist-bangladesh/bangladesh-to-sue-manila-bank-over-81-millioncyber-heist-cenbank-governor-idUSKCN1PO19J.

Ross, S.A. (1976). Options and Efficiency. Quarterly Journal of Economics, $1,75-89$.

Schueffel, P. (2016). Taming the Beast: A Scientific Definition of Fintech. Journal of Innovation Management 4(4), 32-54.

The ASEAN Post. (2019a). Are ASEAN's internet speeds world class? The ASEAN Post. Retrieved from https://theaseanpost.com/article/are-aseans-internetspeeds-world-class\#: :text=Within $\% 20$ the $\% 20$ ASEAN\%20region $\% 2$ C $\% 20$ Thailand,eighth\%20fastest\%20in\%20the\%20world.

The ASEAN Post. (2019b). Strengthening cybersecurity in ASEAN. The ASEAN Post. Retrieved from https://theaseanpost.com/article/strengtheningcybersecurity-asean.

Thomas, J. (2019). ASEAN's data governance challenge. The ASEAN Post. Retrieved from https://theaseanpost.com/article/aseans-data-governancechallenge.

World Bank \& ASEAN WC-FINC. (2019). Advancing Digital Financial Inclusion in ASEAN: Policy and Regulatory Enablers. Retrieved from http://documents1. worldbank.org/curated/en/856241551375164922/pdf/134953-WorldBankASE ANDigitalFinanciallnclusioninASEANpublicationJan.pdf.

World Economic Forum. (2015). The Future of Financial Services: How disruptive innovations are reshaping the way financial services are structured, provisioned and consumed. Retrieved from http://www3.weforum.org/docs/ WEF_The_future_of_financial_services.pdf.

Zimmerman, E. (2016). The Evolution of Fintech. Retrieved from https://www. nytimes.com/2016/04/07/business/dealbook/the-evolution-of-fintech.html. 